\title{
PENGEMBANGAN PENDIDIKAN DAN LINGKUNGAN MASYARAKAT DENGAN PENDEKATAN GOEGRAFI SOSIAL DI DESA WARU
}

\author{
Ikhwan Hamdani ${ }^{1}$, Ginanjar Natasasmita, Afrizal Abdurrohim ${ }^{2}$ \\ ikhwan.hamdani@fai.uika-bogor.ac.id \\ Dosen Fakultas Agama Islam ${ }^{1}$, Mahasiswa KKN Kelompok 16 Tahun $2017^{2}$
}

\begin{abstract}
ABSTRAK
Geografi dalam rumpun ilmu sosial banyak mengembangkan teori sosial, meliputi kependudukan, kebudayaan dan perilaku menyoroti proses ekonomi, proses sosial, proses politik dan proses psikologi (Fielding, 1984). Adapun Teori Geografi banyak menggunakan teori yang dikembangkan dalam rumpun ilmu sosial seperti ekonomi, sosiologi, sejarah, politik dan antropologi memperkuat posisi geografi sebagai bagian yang tak terpisahkan dalam ilmu sosial. Sebagai dasar alat analisis situasi tempat Kegiatan Kuliah Nyata Kelompok 16 yang ada di Desa Waru Kecamatan Parung, Analisis yang digunakan adalah analisis konsep geografi sosial, dimana pendekatan ini terdiri dari 3 aspek: (1) Keruangan, (2) Kelingkungan, dan (3) Kompleks Wilayah. Analisis ini memilki tujuan agar kami dapat melaksanakan program yang dapat membantu mengembangkan pendidikan dan lingkungan di masyarakat Desa Waru. Metode yang digunakan (1) Pendekatan berdasarkan karakter masyarakat, dan (2) Pendekatan organisasi. Dan dalam proses kegiatan kami mengumpulkan informasi dan fakta dengan menggunakan cara (1) Wawancara kepada masyarakat, dan (2) Studi Dokumen. Dengan hasil yang dicapai adalah program kami yang dijalankan sesuai dengan keadaan, kapasitas waktu, dana dan tenaga masyarakat sekitar dan dapat membantu mengurangi permasalahan yang ada berhubungan dengan aspek yang pokok yaitu pendidikan dan lingkungan. Dan dapat menjadi alat analisis yang nantinya dapat digunakan oleh pihak desa dalam pembangunan rencana desa.
\end{abstract}

Kata Kunci : Geografi Sosial, Lingkungan, Pendidikan.

\section{PENDAHULUAN}

Pengambilan data tentang deskripsi
lokasi kegiatan KKN ini dengan
mengambil data sekunder, merupakan
sumber data penelitian yang diperoleh
peneliti secara tidak langsung melalui
media perantara (diperoleh dan dicatat oleh
pihak lain). Data sekunder umumnya
berupa bukti, catatan atau laporan historis
yang telah tersusun dalam arsip (data
dokumenter) yang dipublikasikan dan yang

tidak dipublikasikan. Dan survey lapangan selama waktu KKN berlangsung. Diambil dari Profil Desa Waru tercatat 02 Juli 2016, Desa waru adalah salah satu desa yang terletak di Kecamatan Parung. Dengan luas wilayah 293.39 Ha Wilayah yang terbagi dalam Dusun, 7 Rukun Warga (RW) dan 38 Rukun Tetangga (RT) dengan batas wilayah adalah sebagai berikut: 


\begin{tabular}{|c|l|c|}
\hline No & Keterangan & Berbatasan \\
\hline 1 & Utara & $\begin{array}{c}\text { Desa Cidokom/Desa } \\
\text { Curug Kec. Gunung } \\
\text { Sindur. }\end{array}$ \\
\hline 2 & Selatan & Desa Parung. \\
\hline 3 & Barat & Desa Waru Jaya \\
\hline 4 & Timur & $\begin{array}{c}\text { Desa Parung/Desa } \\
\text { Pemagarsari/Desa } \\
\text { Waru jaya. }\end{array}$ \\
\hline
\end{tabular}

Karena dekat dengan pusat kota bogor memang daerah Waru ini susananya sudah modern atau dibilang desa semi Kota, dilihat dari cara berdaptasinya. Walaupun desa Waru berada dikabupaten Bogor namun dilihat dari bahasa, interaksi lebih kepada suku betawi.

\section{Pemanfaatan Lahan}

\begin{tabular}{|c|l|c|}
\hline No & Keterangan & $\begin{array}{c}\text { Jumlah } \\
\text { (Ha) }\end{array}$ \\
\hline 1 & $\begin{array}{l}\text { Perumahan \ pemukiman } \\
\text { dan pekarangan }\end{array}$ & 87,2 \\
\hline 2 & Sawah & 32,1 \\
\hline 3 & Ladang \Kebun & - \\
\hline 4 & Kuburan & 2 \\
\hline 5 & Pekarangan & 132,1 \\
\hline 6 & Taman & - \\
\hline 7 & Perkantoran & 0,1 \\
\hline 8 & Luas prasarana lainya & 39,9 \\
\hline
\end{tabular}

Adanya pembangunan Proyek pabrik dan perumahan, mengakibatnya berkurangnya tanah resapan di daerah tersebut.

Jumlah Penduduk

\begin{tabular}{|c|l|c|}
\hline No & Jenis Kelamin & Jumlah \\
\hline 1 & Laki-Laki & 3.856 \\
\hline 2 & Perempuan & 3.927 \\
\hline 3 & Kepala Keluarga & 2.267 \\
\hline
\end{tabular}

Untuk kehidupan beragama di desa waru mayoritas adalah agama Islam dan ini sudah merupakan kecocokan tempat kegiatan KKN karena UIKA sendiri adalah Universitas Islam, walaupun begitu kehidupan perbedaan agama ini memiliki hubungan yang harmonis, dilihat tidak adanya kasus permusuhan karena ras agama dan lain sebagainya. Karena lingkungan tempat tinggal KKN 16 Berada di RW 06, oleh karena itu kita sering berdaptasi dengan sebagian masyarakat dan untuk menjadi batasannya kami menyajikan data bahwa masyarakat yang nantinya sering kami temui dan beradaptasi adalah sebagi berikut:

\section{Pendidikan}

\begin{tabular}{|c|l|c|}
\hline No & Tingkat Pendidikan & Jumlah \\
\hline 1 & SD & 3.769 \\
\hline 2 & SMP & 3.710 \\
\hline 3 & SMA & 4.800 \\
\hline 4 & Akademik (D1-D3) & 288 \\
\hline 5 & Sarjana (S1-S3) & 443 \\
\hline 6 & Belum Sekolah & 678 \\
\hline 7 & Sedang Sekolah & 1.582 \\
\hline \multicolumn{2}{|c|}{ Secara umum kondisis sosial politik } \\
\hline
\end{tabular}
serta ketentraman dan ketertiban di wilayah desa Waru cukup terkendali dan harmonis. Dan keadaan masyarakat dari segi pendidikan mayoritas adalah tamat SMA/sederajat

lembaga pendidikan anak Usia Dini di Rw 06 sendiri ada 3 yang sudah terdaftar di pemeritah dan lebih dari 3 masih berkembang namun sudah memiliki murid yang cukup banyak.

\section{Mata Pencaharian}

\begin{tabular}{|c|l|c|}
\hline No & Pekerjaan & Jumlah \\
\hline 1 & Petani & 41 \\
\hline 2 & Peternak & 2 \\
\hline 3 & PNS & 126 \\
\hline 4 & Polri & 15 \\
\hline 5 & Karyawan Pabrik & 2.143 \\
\hline 6 & Wiraswasta & 2.606 \\
\hline 7 & Pelajar & 4.595 \\
\hline 8 & Ibu Rumah Tangga & 3.572 \\
\hline
\end{tabular}




\begin{tabular}{|c|l|c|}
\hline 9 & Buruh Tani & 16 \\
\hline 10 & Pedagang Keliling & 133 \\
\hline 11 & TNI & 15 \\
\hline 12 & Peg. Swasta & 109 \\
\hline 13 & Buruh Harian Lepas & 179 \\
\hline 14 & Sopir & 80 \\
\hline 15 & Belum bekerja & 2.894 \\
\hline 16 & Perangkat Desa & 3 \\
\hline
\end{tabular}

Masyarakat lebih banyak bekerja sabagai buruh pabrik, yang setiap harinya dihabiskan di pabrik jadi untuk interaksinya didaerah tersebut terkesan individu.

Selain itu, Kurangnya pengelolaan sumber daya seperti singkong dijadikan sebagai bahan yang nanti bernilai ekonomis, karena di Desa Waru Rw 06 hasil perkebunan langsung dijual kepasar, diolah hanya untuk konsumsi pribadi. 


\section{METODE PENGABDIAN}

Pelaksanaan KKN di Desa Waru Rw06 ini terhitung selama 7 Agustus-7 September 2017 dengan tahapan pelaksanaan dengan hitungan permingggu berjumlah 4 tahapan, Adapun tahapan pelaksanaan sebagai berikut:

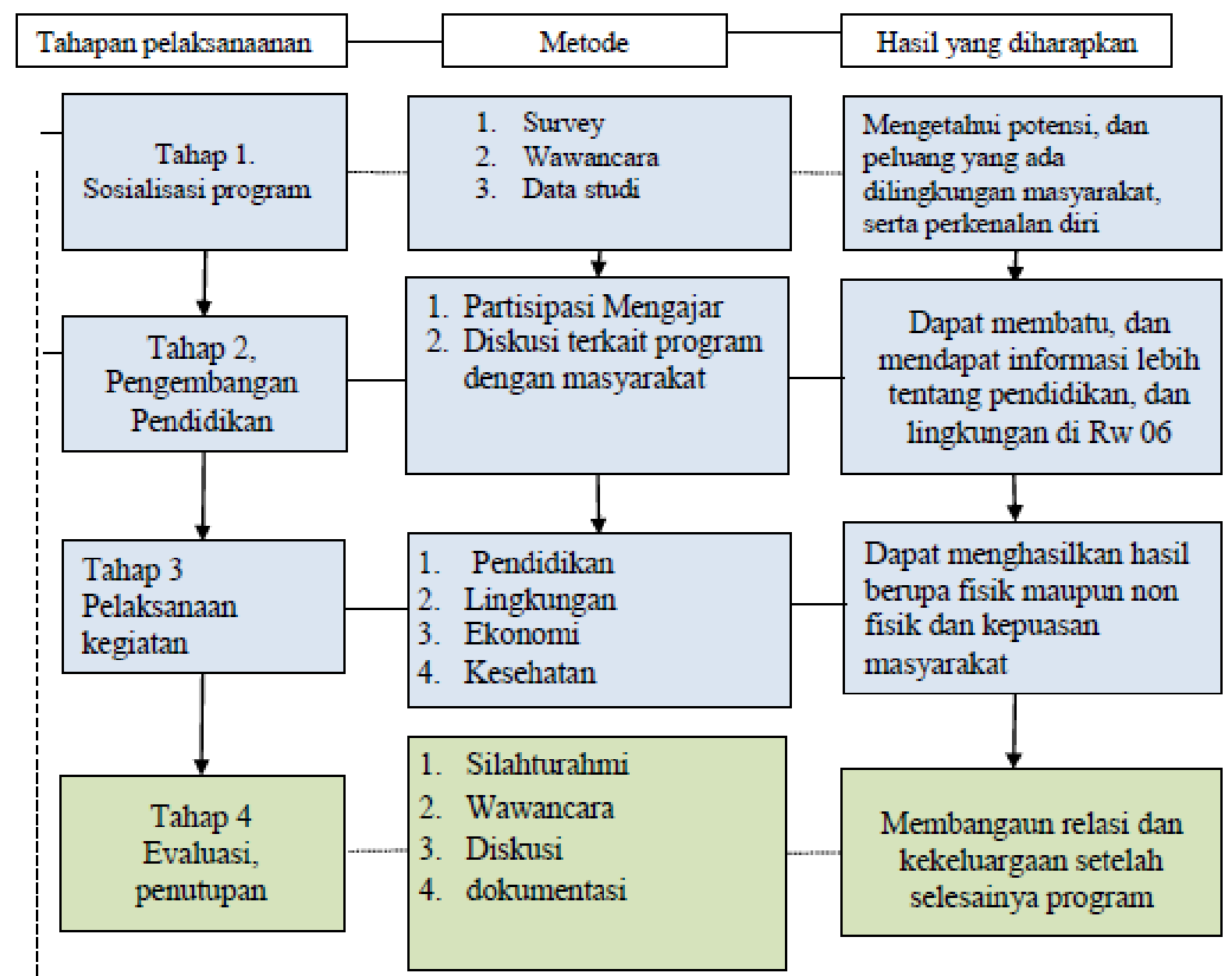

Gambar 3.1: Tahapan Pelaksanaan 
Jadwal Kegiatan

\begin{tabular}{|c|l|c|c|c|c|}
\hline \multirow{2}{*}{ No. Kegiatan } & \multicolumn{2}{|c|}{ Minggu ke- } \\
\cline { 5 - 6 } & & 1 & $\mathbf{2}$ & $\mathbf{3}$ & $\mathbf{4}$ \\
\hline 1 & Penyusunan Rencana Kegiatan & & & & \\
\hline 2 & Sosialisasi Rencana Kegiatan & & & & \\
\hline 3 & $\begin{array}{l}\text { Partisipasi mengajar disekitar Lingkungan } \\
\text { (PAUD, TPA, Bimbel, dsb) }\end{array}$ & & & & \\
\hline 4 & Pembuatan Apotik Hidup & & & & \\
\hline 5 & Pembuatan Jalan Refleksi & & & & \\
\hline 6 & Penyuluhan Menabung Sejak Dini & & & & \\
\hline 7 & Pelatihan Pembuatan Brownis Singkong & & & & \\
\hline 8 & Gerakan Lubang Resapan Biopori & & & & \\
\hline 9 & Seminar Pendidikan Tingkat Desa & & & & \\
\hline 10 & Training Motivasi untuk remaja & & & & \\
\hline 11 & Pembuatan Sarana- Prasarana untuk & & & \\
\hline 12 & Pendidikan dan lingkungan sekitar & & & & \\
\hline 13 & Monitoring dan Evaluasi & & & & \\
\hline 14 & $\begin{array}{l}\text { Penutupan dan Perpisahan dengan warga dan } \\
\text { lembaga terkait }\end{array}$ & & & & \\
\hline 15 & Penyusunan Laporan & & & & \\
\hline
\end{tabular}

\section{Metode Pendekatan}

Pendekatan yang digunakan pada kegiatan ini adalah dengan pendekatan geografi sosial, dimana pendekatan ini terdiri dari 3 aspek: (1) Keruangan, (2) Kelingkungan, dan (3) Kompleks Wilayah. Ketiga aspek tersebut dilihat dari sudut pandang geografi untuk menganalisis dan bagaimana solusi untuk kehidupan sosial masyarakat desa waru. Maka diperlukan strategi dalam pelaksanaanya dengan beberapa pendekatan yang strategis, diantaranya:

1. Pendekatan berdasarkan karakter masyarakat, yakni pembinaan yang dilakukan akan disesuaikan dengan karakter masyarakat. Joyce dan Weil (1996) mengungkapkanbahwa model pendidikan yang relevan dengan perilaku sosial dan nilai adalah dengan banyak memberikan permainan peran. Hal ini dilakukan untuk memberi pengalaman riil kepada peserta didik tentang sesuatu yang dilakukan atau dirasakan oleh orang lain. Memang, dalam prakteknya, tidak seluruh aspek harus menggunakan permainan ini. Dalam beberapa hal, terdapat kegiatankegiatan yang hanya golongan tertentu untuk melakukannya. Sejalan dengan konsep Joyce dan Weil, cooperative learning yang digagas Slavin (2005) 
dapat digunakan untuk membangun kesadaran toleransi masyarakat. Hal ini karena penekanan dari konsep pendidikan ini adalah kerjasama yang merupakan urat nadi toleransi. Dengan demikian, model pendidikan yang akan dibangun menggunakan dua konsep utama yaitu role playing model dan cooperative learning model.

2. Pendekatan organisasi, yaitu pendekatan dimana sebagian kegiatan diorganisir dan bekerja sama dengan lembaga pendidikan dan lembaga masyarakat yang ada di desa Waru .

Dimana dalam pelaksanaan untuk mengetahuhi bagaimana langkah yang perlu ditempuh dan luarannya menjadi solusi untuk pengembangan lingkungan dan pendidikan masyarakat sekitar, oleh karena itu kami memerlukan metode pengambilan data, metode yang digunakan dalam hal ini adalah :

1. Wawancara

Proses memperoleh penjelasan untuk mengumpulkan informasi dengan menggunakan cara tanya jawab bisa sambil bertatap muka ataupun tanpa bertatap muka yaitu melalui media telekomunikasi antara pewawancara dengan yang diwawancarai, dengan ataupun tanpa pedoman. Pada hakikatnya wawancara merupakan kegiatan untuk memperoleh informasi secara mendalam tentang sebuah isu atau tema yang diangkat dalam penelitian. Atau, merupakan proses pembuktian terhadap informasi atau keterangan yang telah diperoleh lewat teknik yang lain sebelumnya (Sujarweni: 2015).

2. Studi Dokumen

Metode pengumpulan data kualitatif sejumlah besar fakta dan data tersimpan dalam bahan yang berbentuk dokumentasi. Sebagian besar data berbentuk surat, catatan harian, arsip foto, hasil rapat, jurnal kegiatan dan lain sabagainya. Data jenis ini mempunyai sifat utama tak terbatas pada ruang dan waktu sehingga bisa dipakai untuk menggali informasi yang terjadi dimasa silam. (Sujarweni: 2015)

\section{Partisipasi Masyarakat dalam Pelaksanaan Program}

Partisipasi masyarakat yang dapat dilakukan dalam kegiatan ini adalah sebagai berikut:

1. Bersedia untuk diwawancarai terkait dengan berjalannya program.

2. Mempersiapkan tempat untuk penyuluhan lingkungan dan pendidikan.

3. Menjadi rekan kerjasama dalam beberapa kegiatan.

4. Partisipasi dan memeriahkan beberapa program.

5. Bersama-sama dengan Tim Pengusul melakukan kegiatan dan berdiskusi terkait berjalannya program pengembangan pendidikan dan lingkungan

\section{Langkah Evaluasi}

Evaluasi yang akan dilakukan terdiri dari:

1. Evaluasi Masukan meliputi pertimbangan tentang sumber dan strategi yang diperlukan untuk mencapai tujuan terlaksananya program. Informasi-informasi yang terkumpul selama tahap penilaian hendaknya dapat digunakan untuk menentukan sumber dan strategi didalam keterbatasan dan hambatan yang ada.

2. Evaluasi proses, yang terkait dengan perencanaan, pelaksanaan dan monitoring kegiatan. Evaluasi proses 
akan dilakukan setiap pekan bersama dengan seluruh anggota KKN 16.

3. Evaluasi Hasil penilaian dalam mengukur keberhasilan pencapaian program bersifat fisik maupun non fisik, penilaian tersebut dikembangkan dan diadmistrasikan. Sehingga data yang dihasilkan sangat berguna bagi anggota dan masyarakat setempat dalam menentukan apakah program, diteruskan, dimodivikasi atau dihentikan.

\section{REALISASI PROGRAM}

Pelaksanaan program ini dilaksanakan oleh seluruh tim pelaksana yang terbagi kedalam 4 bidang yang terlampir dalam lampiran susunan kepengurusan. Adapun pelaksanaan program adalah sebagai berikut:

\section{Program Bidang Pendidikan}

a. Keaksaraan Fungsional

Keaksaraan fungsional merupakan suatu pendekatan atau cara untuk mengembangkan kemapuan seseorang dalam menguasai dan menggunakan keterampilan menulis, membaca dan menghitung yang berorientasi pada kehidupan sehari-hari serta memanfaatkan potensi yang ada di lingkungan sekitarnya.

b. Kegiatan Mengajar PAUD

Program Kegiatan PAUD adalah seperangkat bahan ajar yang direncanakan sebagai pedoman dalam melaksanakan kegiatan pendidikan dalam mengembangkan kemampuan dan potensi anak sesuai karakteristik dan lingkungannya

c. Seminar Pendidikan
Seminar pendidikan ini di tunjukkan untuk para pendidik atau guru SeDesa Waru, melihat dari analisis yang ada bahwa para pendidik jenjang pendidikan dan masih perlunya adanya penghubung antara lembaga resmi kependidikan anak usia dini dan para pendiri pendidikan anak usia dini.

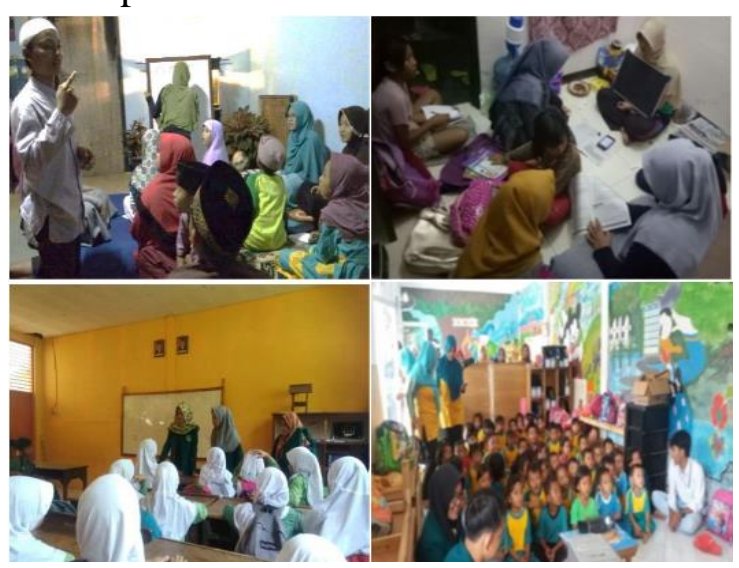

d. Pengajian rutin TPA dan Bimbel

Melihat banyaknya anak-anak yang belum pandai mengaji kami mengadakan program pengajian rutin anak anak setiap hari bada maghrib dengan dibantu oleh pemudapemuda sekitar tempat pengajian. Sedangkan Bimbingan Belajar sasarannya adalah anakanak yang berada disekitar lingkungan posko kami dengan berbagai macam mata pelajaran, seperti IPA, IPS, Agama Islam , Bahasa Indonesia, Inggris, dan Arab.

e. Training Motivasi

Training atau pelatihan adalah kegiatan yang dirancang untuk meningkatkan kinerja dalam melakukan pekerjaan, baik pekerjaan secara fisik ataupun pekerjaan yang berhubungan dengan orang lain, terutama dalam mengembangkan diri kita. 


\section{Program Bidang Lingkungan}

Pada bidang lingkungan ini dari analisis pendekatan Geografi sosial, lebih kepada ilmu lingkungan. ilmu lingkungan adalah penerapan berbagai prinsip dan ketentuan ekologi dalam kehidupan manusia

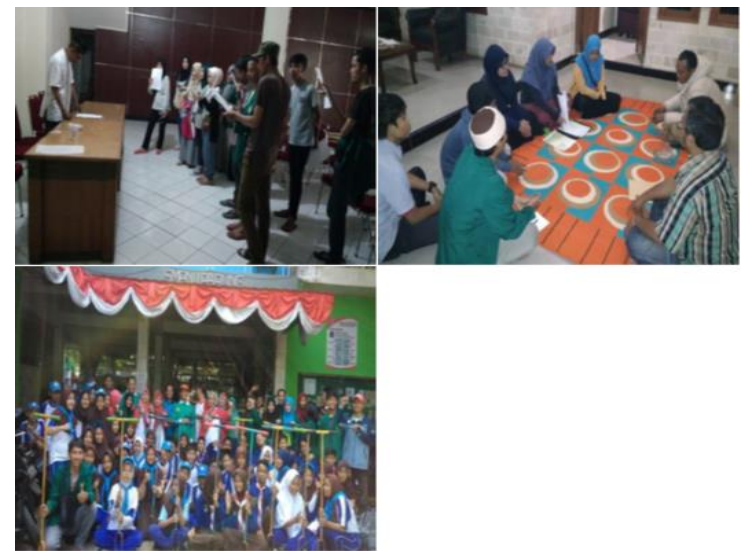

a. Penyuluhan Pembuatan Lubang Resapan Biopori

yang bertujuan ketika tanah itu dilubangi dan diisi sampah organik karena sebagai sumber makanan makluk yang hidup di dalam tanah sehingga tanah menjadi hidup dan subur

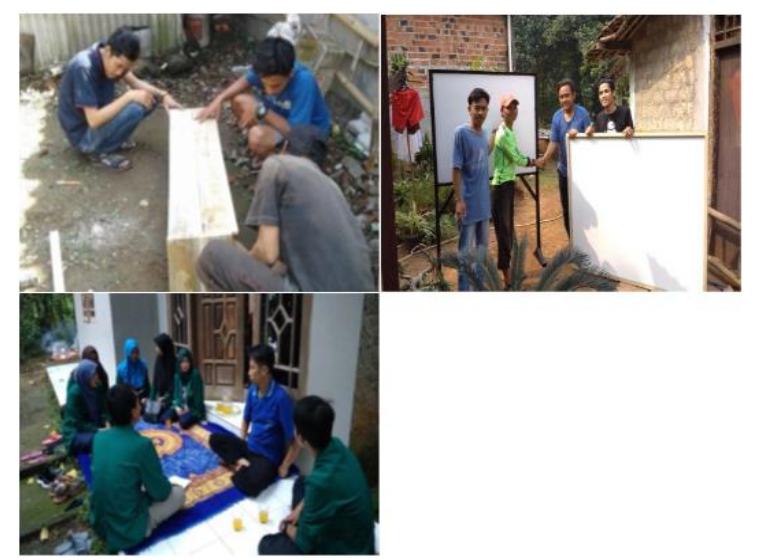

b. Membuat Sarana-Prasarana untuk Pendidikan

Melihat keadaan yang kurang kondusif saat kegiatan ajar mengajar, karena itu kami inisiatif untuk membuat sarana yang dapat membantu dalam kegiatan pengajaran di dalam Bidang Pendidikan. c. Penempatan hasil karya tangan tong sampah non permanen dan Spanduk

\section{Program Bidang Ekonomi}

a. Penyuluhan Menabung Sejak Dini

Menabung secara sederhana merupakan langkah menyisihkan sebagian dana dari penghasilan kita, tentu kebiasaan menabung ini harus mulai di tanam sejak dini.

b. Pelatihan membuat brownis singkong kukus keju.

Melihat Keadaan Geografis dimana kebanyakan di Rw 06 lahan digunakan untuk kebon singkong, dan hasil dari kebun itu biasanya langsung dijual kepasar atau tengkulak, dan jarang dari masyarakat setempat mengolah lansung singkong dan bernilai ekonomis.

\section{Program Bidang Kesehatan}

Melihat antusias masyarakat yang masih kurang partisipasi pada unit kesehatan yang telah tersedia di desa, dengan berbagai sudut pandang mulai dari tata letak tempat Puskesmas Pembantu yang kurang strategis, Sosialisasi yang kurang, atau Kurang pedulinya masyarakat tentang pentingnya hidup sehat

a. Jalan Refleksi
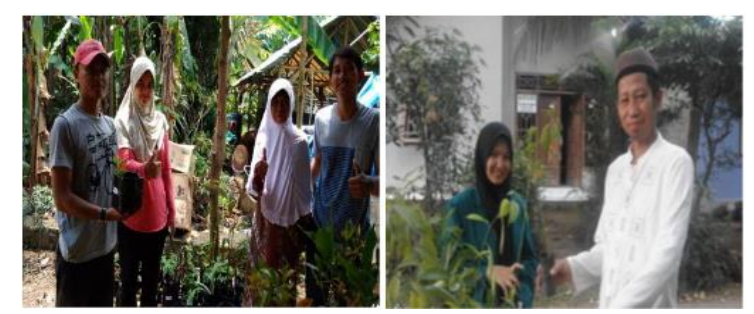

b. Apotik Obat 


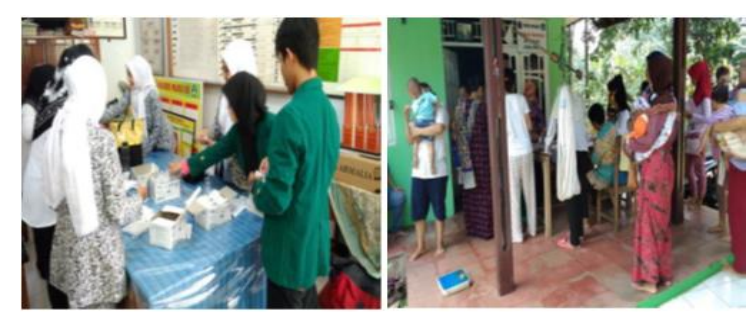

c. Posyandu

\section{KESIMPULAN}

Dengan Pendekatan Geografi sosial, muncul program kerja yang terlaksana, namun masih perlunya banyak masukan, melihat judul diatas merupaka lintas ilmu yang kami paraktekkan namun tidak mengurangi semangat dalam pelaksanaan kegiatan $\mathrm{KKN}$, dengan waktu yang begitu singkat, kami berusaha menyesuaikan dana, tenaga dan waktu dan inilah kesimpulan yang telah tersusun:

a. Program Terlaksana, tepat sasaran, dan sesuai dengan rencana yang dibuat bahkan lebih dari target yang kami buat.

b. Antusias masyarakat dengan menyambut kedatangan kami, dan mendukung program kami hingga, berlanjutnya komunikasi dengan warga dan masyarakat terkait program yang yang telah terlaksana.

c. Seluruh Program Kerja yang terlaksana saling berkaitan dengan tema KKn 16 tentang pengemangan Pendidikan dan Lingkungan.

\section{Dampak Bagi Masyarakat}

Dari seluruh Kegitan KKN yang dilaksanakan dampak bagi masyarakat khususnya di desa Waru, memiliki dampak yang pendek dan berkepanjangan, langsung maupun tidak langsung, dan berbentuk fiksik maupun non fisik:

\section{Dampak Pendek dan berkepanjangan}

Dampak pendek yang hanya dirasakan pada waktu saat kami disana melaksanakan tugas KKN seperti, kegiatan mengajar yang kami lakukan seperti Bimbel ini dirasakan perbedaannya oleh masyarakat sekitar, membantu mengajar TPA, PAUD dan sebagainya.

Dampak yang berkepanjangan seperti halnya kami membuat kenangkenangan berupa papan tulis, meja, spanduk, lubang biopori yang memang itu semua berbentuk fisik dan terlihat, dan yang paling penting adalah masih berlanjutnya komunikasi dan silahturahmi dengan masyarakat.

2. Langsung dan Tidak langsung

Dampak Langsung adalah langsung kepada sasaran seperti halnya,diadakannya seminar supaya bertambahnya metode belajar itu akan berdampak langsung terhadap pengajaran dan secara tidak langsung akan berdampak pada kepuasan anakanak dan orang tuanya. Sama seperti apotik hidup dimana dampaknya untuk kesehatan masyarkat secara langsung dan tidak langsungnya memberikan pendidikan dan sarana untuk mendapatkan tanaman obat yang kadang sulit ditemukan.

\section{Fisik maupun Non Fisik}

Dampak fisik yaitu dampak yang terlihat dengan indra penglihat seperti pembuatan jalan refleksi, tong sampah yang ada bentuk fisik dan dapat langsung digunakan oleh masyarakat, Adapun non fisiknya seperti kepuasan rohani yang tidak seorang pun dapat melihatnya, dan hanya dirasakan oleh individu itu sendiri, seperti setelah terselenggaranya seminar, training motivasi yang memberikan kepuasan 
dan bahkan berubahan sikap yang tidak terlihat bentuknya namun, dalam maknanya.

\section{SARAN}

Dengan Hasil dan pembahasan yang telah dilaksanakan dan dibuat laporannya, kami penulis memiliki rekomendasi untuk dijadikan pertimbangan terkait untuk pengabdian dan pengembangan desa khususnya desa waru. Terbitnya UU Desa No. 6 Tahun 2014 telah membuka peluang besar bagi desa yang ada di seluruh Indonesia, untuk dapat melakukan pembangunan didesanya dengan harapan dapat meningkatkan kesejahteraan masyarakat desa. Desa juga diberikan kapasitas keuangan yang besar oleh pemerintah pusat, sehingga mampu membiayai pembangunannya sendiri pada tingkat desa dan kawasan pedesaan.

Dalam pembangunan daerah diperlukannya sistem perencanaan, tata kelola, ekologi dan semua itu telah tercover dalam analis menggunakan metode geografi sosial yang telah dipaparkansecara singkat, sehingga pembangunan daerha dapat tepat sasaran, dan sesuai dengan potensi lingkungan, masyarakat yang ada. Dan pembangunan yang dilakukan bukan menjadi penghambat, dan timbulnya masalah baru, namun merupakan solusi dari permasalahan yang ada. 


\section{REFERENSI}

Fielding, G.J (1984). Geography As Social Science. Harper and Row Publishers: London.

Iskandar. J. (2014). Manusia dan Lingkungan dengan Berbagai Perubahannya. Graha Ilmu: Yogyakarta.

Joyce, Bruce dan Weil, Marsha. (1996). Models of Teaching. Boston: Allyn and Bacon

Lumbantoruan. W. (2001). Pendekatan Geografi Sebagai Cirikhas Ilmu Geografi.. Jurnal

Pendidikan Science. Vol 25 No. 3, (28-35). Diakses dari www.digilid.unimed.ac.id

Pedoman Pelaporan PPM UIKA. (2017)

Sumaatmaja. (1981). Studi Geografi Suatu Pendekatan Dan Analisa Keruangan. Alumni: Bandung

Sujarweni . V . W. (2015). Metodologi Penelitian Bisnis \& Ekonomi. PT Pustaka Baru: Yogyakarta.

Sumantri. A. (2013). Kesehatan Lingkungan. PT Fajar Interpratama Mandiri: Jakarta.

Profil, Lembaga Pendidikan Anak Usia Dini Tunas Bangsa

Survey lokasi. (2017) Desa Waru

Wawancara. (2017) Desa Waru
Profil Desa. (2016) Desa Waru

Internet:

hhtps://kbbi.web.id/eksistensialisme/fenom enologi.html

hhtps://mithaariany.wordpress.com/2012/0 5/27/pendekatan-keruangan-ekologipendekatankompleks-wilayah/

https://efishery.com/efisheryuniversity/siar/bioflok-suplemenalami-bagi-ikan/

https://himpaudikadudampit.wordpress.co m/himpaudi-kecamatan-kadudampitkabupatensukabumi-jabar-jawabarat/ 